\title{
Soil Management in the Breede River Valley Wine Grape Region, South Africa. 1. Cover Crop Performance and Weed Control
}

\author{
J.C. Fourie \\ ARC Infruitec-Nietvoorbij, Private Bag X5026, Stellenbosch, 7599 Republic of South Africa \\ Submitted for publication: August 2009 \\ Accepted for publication: January 2010 \\ Key words: Cover crops, mulches, management practices, weed control, grapevines.
}

\begin{abstract}
Eight cover crop treatments were applied for 12 consecutive years on a medium-textured soil in a vineyard near Robertson (33 $\left.50^{\prime} \mathrm{S}, 1^{\circ} 54^{\prime} \mathrm{E}\right)$. A treatment with full surface straw mulch and full surface post-emergence chemical control applied from just before grapevine bud break to harvest $(\mathrm{BB})$, and one with no cover crop combined with $\mathrm{BB}$, were also applied. The control consisted of mechanical control in the work row and post-emergence chemical control in the vine row applied from bud break to harvest. Rotating Triticale v. Usgen 18 (triticale) and Vicia dasycarpa Ten. (vetch) did not improve the dry matter production (DMP) of either species. Average DMP decreased as follows: triticale $>$ Secale cereale L. v. Henog (rye)/Vicia faba L. v. Fiord (faba bean) mixture > triticale/vetch biennial rotation $>$ triticale/vetch annual rotation $>$ vetch. Triticale (BB) resulted in total winter weed suppression from 1995 to 1996 and from 2001 to 2004. Total weed control from bud break to the pea size berry stage of the grapevines was achieved with straw mulch (BB), triticale (BB), rye/faba bean mixture (BB) and triticale/vetch rotated biennially (BB) from 2001 to 2003. For triticale combined with full surface post-emergence chemical control applied from grapevine berry set $(\mathrm{AB})$, and for triticale/vetch rotated annually (BB), this was restricted to 2001 and 2003 . From the pea size berry stage to harvest, straw mulch $(\mathrm{BB})$, triticale $(\mathrm{BB})$, vetch $(\mathrm{BB})$, rye/faba bean mixture $(\mathrm{BB})$ and triticale $(\mathrm{AB})$ reduced the weed stand significantly in comparison to the control.
\end{abstract}

\section{INTRODUCTION}

Effective and sustainable weed control is essential, as uncontrolled weeds may reduce crop yield by as much as $80 \%$ (Cousens \& Mortimer, 1995). Reasons to reduce herbicide use are the widespread appearance of herbicide-resistant weeds (Darmency \& Gasquez, 1990; LeBaron \& McFarland, 1990; LeBaron, 1991; Henkes, 1997; Powles et al., 1997), the risk of environmental contamination (Carter et al., 1991), and negative public perceptions of agrochemicals (Major, 1992). Cover crop management is a non-specific biological method of pre-emergence weed control (Van Huyssteen et al., 1984; Fourie et al., 2001) that has many advantages, inter alia the reduction of water runoff and erosion (Khan et al., 1986; Roth et al., 1988; Louw \& Bennie, 1992), restriction of evaporation from the soil surface (Van Huyssteen et al., 1984), soil water conservation (Buckerfield \& Webster, 1996), and the reduction of temperature fluctuations in the soil (Van Huyssteen et al., 1984).

For cover crop management to be successful, a cover crop should be able to compete effectively with the winter-growing weeds prevalent in a region, as well as to produce enough dry matter to create mulch that will effectively control summer-growing weeds (Fourie et al., 2006a). The difference in climate between regions, as well as the spectrum of winter-growing weeds in a specific region, has an effect on the performance of cover crop species (Fourie et al., 2001). In a trial on open-land Triticale v. Usgen 18 (triticale), Secale cereale L. v. Henog (rye), Vicia faba L. v.
Fiord (faba bean) and Vicia dasycarpa Ten (vetch) were identified as the species most suitable for cover crop management in the Breede River Valley wine grape region (Fourie et al., 2006a). Fourie et al. (2005) indicated that vetch was one of the species for which an increase in dry matter production during winter resulted in improved weed suppression during both winter and summer. The perennial grass Festuca arundinaceae L. v. Cochise (dwarf Fescue), slashed regularly throughout the grapevinegrowing season, suppressed both winter- and summer-growing weeds effectively, but eventually became infested with Cynodon dactylon (L.) Pers. (common couch) (Fourie, 2005). However, the effect of these cover crops on the winter- and summer-growing weeds in the vineyards of the Breede River Valley wine grape region is not known.

This study was carried out to determine the effect of different cover crop management practices on cover crop performance, as well as the effect of different soil cultivation practices on winter and summer weed growth. The aim is to supply the wine grape industry with guidelines for sustainable weed control over the long-term in vineyards established on medium-textured soils in the Breede River Valley wine grape region.

\section{MATERIALS AND METHODS}

\section{Experimental vineyard and layout}

The trial was carried out in a Chardonnay/99 Richter vineyard trained on a seven-strand double lengthened Perold trellis system 
(Booysen et al., 1992) that was established on a medium-textured soil (Table 1) at the ARC Infruitec-Nietvoorbij research farm near Robertson during November 1992. The soil was classified as a Tukulu, using the South African Soil Classification System (Soil Classification Work Group, 1991). The soil was described as a sandy clay loam with a poorly defined A horizon (0 to $300 \mathrm{~mm}$ ) grading into a B horizon (300 $\mathrm{mm}$ to $1.05 \mathrm{~m}$ ), characterised by a weakly developed cutanic structure overlying unspecified material with signs of wetness. Robertson ( $\left.33^{\circ} 50^{\prime} \mathrm{S}, 19^{\circ} 54^{\prime} \mathrm{E}\right)$ is situated in the Breede River Valley region of the Western Cape. Mean annual rainfall amounts to $278 \mathrm{~mm}$, of which approximately $178 \mathrm{~mm}$ precipitates from March to August. The vines were spaced $1.5 \mathrm{~m}$ in the row and $2.75 \mathrm{~m}$ between rows. The soil was analysed for $\mathrm{pH}(1.0 \mathrm{M} \mathrm{KCl}), \mathrm{P}$ and $\mathrm{K}$ (Bray II), exchangeable $\mathrm{K}, \mathrm{Ca}, \mathrm{Mg}$ and $\mathrm{Na}$ (extracted with $0.2 \mathrm{M}$ ammonium acetate), and organic carbon by the Walkley-Black method (The Non-affiliated Soil Analysis Work Committee, 1990). Soil samples were taken from the 0 to $300 \mathrm{~mm}$ and 300 to $600 \mathrm{~mm}$ soil layers during March 1993, before the treatments were initiated and analysed (Table 1).

Eleven treatments were applied, as shown in Table 2. The cover crops were sown annually during mid-April (seeding dates varying between 4 and 15 April) at seeding densities suggested by Fourie et al. (2001), with the exception of 1993, when infrastructural work delayed sowing until 24 May. Seedbed preparation was done with a disc harrow approximately six weeks before the seeding date. Vetch and faba bean were inoculated with Rhizobium leguminosarum biovar viciae bacteria just before sowing. After sowing by hand, the seeds were covered using a disc harrow. Post-emergence weed control was applied with glyphosate at a rate of $1.44 \mathrm{~kg} / \mathrm{ha}$ (active ingredient) by means of a tractor sprayer. Triticale was flattened with a roller approximately three weeks after being controlled chemically to create a mulched soil surface.

The vineyard was irrigated by means of $25.7 \mathrm{~L} / \mathrm{h}$ microsprinklers that had a $360^{\circ}$ wetting pattern. The micro-sprinklers were installed on the irrigation line in the upright position at 1.5 $\mathrm{m}$ intervals. The cover crops received $16 \mathrm{~mm}$ of water (irrigation or rainfall) per week during the first eight weeks after being sown, after which they received $16 \mathrm{~mm}$ water (irrigation or rainfall) fortnightly up to the end of August, as suggested by Fourie et al. (2001).

All the treatments received $14 \mathrm{~kg} / \mathrm{ha}$ of $\mathrm{N}$ (50 kg of limestone ammonium nitrate) during seedbed preparation, as well as $14 \mathrm{~kg} /$ ha of $\mathrm{N}$ at the two- to four-leaf development phases of the grass cover crops. In the case of the $\mathrm{N}$-fixing broadleaf cover crops, the $\mathrm{N}$ was applied to the vine row only, while in the other treatments it was broadcast.

\section{Measurements}

Dry matter production (DMP) by both the cover crops and the associated weeds was determined just before grapevine bud break (end of August), when the grapevine berries reached pea size (end of November) and just before harvest (end of January), according to the procedure described by Fourie et al. (2001).

\section{Statistical procedures}

The experiment was a completely randomised design, with 11 treatments replicated four times. The experiment was repeated for 12 consecutive seasons (years). The size of each unit (plot) was $165 \mathrm{~m}^{2}$. All variables were measured at random sites within each experiment unit at the end of August, the end of November and the end of January (only for the first five seasons). Analyses of variance were performed for each season separately, using SAS (SAS, 1990). Student's $t$ least significant difference (LSD) was calculated at the $5 \%$ significance level to facilitate comparison between the treatment means. The Shapiro-Wilk test was performed to test for non-normality (Shapiro \& Wilk, 1965).

\section{RESULTS AND DISCUSSION}

\section{Dry matter production of cover crops}

The DMP of the cover crop species in all the treatments, as measured at the end of August, was lower during 1993 than in the 1994 to 1996 seasons (Table 3). This was attributed to the fact that the cover crops could only be sown late in May during 1993, compared to mid-April during the other seasons. This finding supports the results of Fourie et al. (2006a), which indicate that these cover crops should be established during the second week of April in this region. With the exception of 1994, triticale produced significantly more dry matter than the local weeds measured in T1 (control) and T2, if sown in mid-April (Table 3) and irrespective of the management practice applied. The reason for the relatively low DMP of triticale during 1994 compared to the 1995 to 2003 seasons is not clear, as it did not correlate with differences in the rainfall and temperature between years (data not shown). The dry matter produced by triticale was similar to that reported by Fourie et al. (2006a). The relatively low DMP of triticale during 2004 compared to the 1995 to 2003 seasons (Table 3 ) could be attributed to the continuous use of the species for 12 consecutive years. This might have resulted in an eventual build-up of soil-borne diseases that affect the species (Lamprecht et al., 1988; Lamprecht et al., 1990). However, confirming this was beyond the scope of this study. The rye/faba bean mixture (T8) produced significantly more dry matter than the weeds in T1 (control) and T2 in some years, but on average over the 12-year period only exceeded the weed stand in T2 significantly. Irrespective of the management practice

\section{TABLE 1}

Analyses of the medium textured soil near Robertson determined before the treatments commenced (sampled March 1993).

\begin{tabular}{|c|c|c|c|c|c|c|c|c|c|c|c|c|}
\hline \multirow{2}{*}{$\begin{array}{l}\text { Sample layer } \\
(\mathbf{m m})\end{array}$} & \multirow{2}{*}{$\begin{array}{l}\text { Clay } \\
(\%)\end{array}$} & \multirow{2}{*}{$\begin{array}{l}\text { Silt } \\
(\%)\end{array}$} & \multirow{2}{*}{$\begin{array}{c}\text { Sand } \\
(\%)\end{array}$} & \multirow{2}{*}{$\begin{array}{c}\mathrm{pH} \\
(\mathrm{KCl})\end{array}$} & \multirow{2}{*}{$\begin{array}{c}\text { Electrical } \\
\text { conductivity } \\
(\mathrm{mS} / \mathrm{m})\end{array}$} & \multirow{2}{*}{$\begin{array}{c}\text { Organic C } \\
(\%)\end{array}$} & \multirow{2}{*}{$\begin{array}{c}P \\
(\text { Bray II) } \\
(\mathrm{mg} / \mathrm{kg})\end{array}$} & \multirow{2}{*}{$\begin{array}{c}\text { K } \\
\text { (Bray II) } \\
(\mathrm{mg} / \mathrm{kg})\end{array}$} & \multicolumn{4}{|c|}{ Exchangeable cations $(\mathrm{cmol}(+) / \mathrm{kg})$} \\
\hline & & & & & & & & & $\mathbf{C a}$ & Mg & $\mathbf{K}$ & $\mathbf{N a}$ \\
\hline $0-300$ & 26.15 & 11.01 & 62.84 & 7.4 & 55 & 0.61 & 57 & 408 & 12.02 & 3.33 & 1.16 & 0.22 \\
\hline $300-600$ & 27.00 & 11.00 & 62.00 & 7.4 & 52 & 0.46 & 38 & 286 & 13.62 & 4.02 & 0.87 & 0.34 \\
\hline
\end{tabular}


TABLE 2

Treatments applied from April 1993 to March 2005.

\begin{tabular}{|c|c|}
\hline Treatment & \multirow{2}{*}{ Treatment code } \\
\hline Management practice applied & \\
\hline $\begin{array}{l}\text { No cover crop, post-emergence chemical control of a } 1 \mathrm{~m} \text { wide strip in the vine row and mechanical control in the work row from just before } \\
\text { grapevine bud break (end of August) to just before harvest (end of January) }\end{array}$ & T1 (Control) \\
\hline No cover crop, full surface post-emergence chemical control from the end of August to the end of January (BB) & $\mathrm{T} 2$ \\
\hline $\begin{array}{l}\text { Full surface straw mulch packed out annually approximately two weeks after grapevine bud break (third week of September) at a density } \\
\text { of } 8 \text { tons/ha, BB }\end{array}$ & $\mathrm{T} 3$ \\
\hline Triticale v. Usgen 18 (triticale) sown annually at a seeding density of $100 \mathrm{~kg} / \mathrm{ha}, \mathrm{BB}$. & $\mathrm{T} 4$ \\
\hline $\begin{array}{l}\text { Triticale sown annually at a seeding density of } 100 \mathrm{~kg} / \mathrm{ha} \text {. Post-emergence chemical control of a } 1 \mathrm{~m} \text { wide strip in the vine row at the end of } \\
\text { August and full surface post-emergence chemical control from when the berries reached pea size (end of November) to the end of January (AB) }\end{array}$ & T5 \\
\hline Vicia dasycarpa Ten. (vetch) sown annually at a seeding density of $50 \mathrm{~kg} / \mathrm{ha}, \mathrm{BB}$ & T6 \\
\hline Vetch sown annually at a seeding density of $50 \mathrm{~kg} / \mathrm{ha}, \mathrm{AB}$ & $\mathrm{T} 7$ \\
\hline $\begin{array}{l}\text { A Secale cereale L. v. Henog (rye) and Vicia faba L. v. Fiord (faba bean) mixture sown annually at a seeding density of } 50 \mathrm{~kg} / \mathrm{ha} \text { and } 60 \mathrm{~kg} / \mathrm{ha} \\
\text { respectively, BB. }\end{array}$ & $\mathrm{T} 8$ \\
\hline Triticale (seeding density: $100 \mathrm{~kg} / \mathrm{ha}$ ) and vetch (seeding density: $50 \mathrm{~kg} / \mathrm{ha}$ ) rotated annually, $\mathrm{BB}$ & T9 \\
\hline Triticale (seeding density: $100 \mathrm{~kg} / \mathrm{ha}$ ) and vetch (seeding density: $50 \mathrm{~kg} / \mathrm{ha}$ ) rotated biennially, BB & $\mathrm{T} 10$ \\
\hline $\begin{array}{l}\text { Festuca arundinacae L. v. Cochise (dwarf Fescue) sown during } 1993 \text { and } 1998 \text { at a seeding density of } 15 \mathrm{~kg} / \mathrm{ha} \text {. Chemical control of a } 1 \mathrm{~m} \\
\text { wide strip in vine row from the end of August to the end of January and slashing in the work row throughout the season }\end{array}$ & $\mathrm{T} 11$ \\
\hline
\end{tabular}

\section{TABLE 3}

Effect of different soil cultivation practices on dry matter production (DMP) of different cover crops, measured just before grapevine bud break (end of August) on a medium-textured soil near Robertson.

\begin{tabular}{|c|c|c|c|c|c|c|c|c|c|c|c|c|c|}
\hline \multirow{2}{*}{ Treatment } & \multicolumn{13}{|c|}{ DMP (t/ha) } \\
\hline & $1993^{1}$ & 1994 & 1995 & 1996 & 1997 & 1998 & 1999 & 2000 & 2001 & 2002 & 2003 & 2004 & Average \\
\hline No cover crop, $\mathrm{MC}^{2}$ (Control) & 1.34 & 5.10 & 2.77 & 2.69 & 2.48 & 1.57 & 1.93 & 1.94 & 2.45 & 1.45 & 1.83 & 0.92 & 2.21 \\
\hline No cover crop, $\mathrm{BB}^{3}$ & 0.80 & 2.40 & 2.34 & 3.15 & 1.49 & 1.53 & 2.09 & 1.38 & 2.38 & 1.69 & 1.67 & 0.97 & 1.82 \\
\hline Full surface straw mulch, BB & 7.65 & 3.20 & 7.76 & 8.66 & 2.95 & 4.78 & 7.93 & 6.01 & 4.62 & 5.90 & 6.57 & 6.37 & 6.03 \\
\hline Triticale v. Usgen 18 (triticale), BB & 1.03 & 3.40 & 6.24 & 7.27 & 7.99 & 5.75 & 7.68 & 7.93 & 8.14 & 6.88 & 6.18 & 3.90 & 6.03 \\
\hline Triticale, $\mathrm{AB}^{4}$ & 2.01 & 3.40 & 6.27 & 5.89 & 9.45 & 5.20 & 5.62 & 6.93 & 6.50 & 8.53 & 5.43 & 3.39 & 5.72 \\
\hline Vicia dasycarpa Ten. (vetch), BB & 1.33 & 3.20 & 3.27 & 3.26 & 1.78 & 1.09 & 4.25 & 1.07 & 1.59 & 1.40 & 1.26 & 1.87 & 2.10 \\
\hline Vetch, $\mathrm{AB}$ & 0.86 & 2.20 & 3.47 & 3.17 & 2.40 & 0.81 & 3.77 & 1.55 & 1.22 & 1.23 & 2.64 & 2.31 & 2.14 \\
\hline $\begin{array}{l}\text { Secale cereale L. v. Henog (rye)/ } \\
\text { Vicia faba L. v. Fiord (faba bean) } \\
\text { mixture, BB }\end{array}$ & 1.46 & 3.60 & 3.25 & 5.89 & 3.96 & 4.74 & 5.04 & 4.25 & 4.57 & 4.39 & 5.05 & 4.00 & 4.18 \\
\hline Triticale/vetch rotated annually, BB & $1.26^{\mathrm{t}}$ & 2.40 & $6.37^{t}$ & 3.48 & $7.16^{\mathrm{t}}$ & 0.09 & $8.34^{t}$ & 0.74 & $7.50^{\mathrm{t}}$ & 1.00 & $5.49^{\mathrm{t}}$ & 3.66 & 3.87 \\
\hline Triticale/vetch rotated biennially, BB & $1.60^{\mathrm{t}}$ & $4.40^{\mathrm{t}}$ & 3.19 & 3.69 & $6.40^{t}$ & $5.11^{\mathrm{t}}$ & 4.01 & 0.59 & $8.54^{\mathrm{t}}$ & $7.80^{\mathrm{t}}$ & 1.34 & 2.48 & 4.10 \\
\hline $\begin{array}{l}\text { Festuca arundinacae L. v. Cochise } \\
\text { (dwarf Fescue), } \mathrm{SL}^{5}\end{array}$ & 0.31 & 3.20 & 1.70 & 3.76 & 1.49 & 0.66 & 1.90 & 1.84 & 3.05 & 2.15 & 1.60 & 2.10 & 1.98 \\
\hline $\operatorname{LSD}(\mathrm{p} \leq 0.05)$ & 0.59 & 2.10 & 2.54 & 2.27 & 2.59 & 2.32 & 2.82 & 2.18 & 2.59 & 2.20 & 3.34 & 1.66 & 2.27 \\
\hline
\end{tabular}

${ }^{1}$ Cover crops established on 24 May instead of mid-April. ${ }^{2} \mathrm{MC}=$ post-emergence chemical control in vine row and mechanical control in working row from the end of August. ${ }^{3} \mathrm{BB}=$ full surface post-emergence chemical control from the end of August. ${ }^{4} \mathrm{AB}=$ post-emergence chemical control in vine row at the end of August, full surface post-emergence chemical control from when the grape berries reached pea size (end of November). ${ }^{5} \mathrm{Chemical}$ control in vine row from the end of August, work row slashed throughout the season. 'Year in which triticale was sown. 
applied, vetch did not produce significantly more dry matter than the weeds in T1 (control) and T2, except during 2004 in T9 (the treatment in which vetch and triticale were rotated annually). The amounts of dry matter produced by vetch in this study were lower than those reported by Fourie et al. (2006a), but did not decline after being sown for four consecutive years, as reported for the species in the Coastal wine grape region (Fourie et al., 2006b). Similar results were achieved with dwarf Fescue in T11 (Table 3). Rotating triticale and vetch annually (T9) or biennially (T10) did not improve the performance of either species in comparison with the treatments in which these species were sown as a monoculture for 12 consecutive years. The long-term average of the different treatments indicated that, overall, DMP decreased as the role of the nitrogen-fixing species became more prominent in the cover crop management system, namely triticale monoculture $>$ rye/ faba bean mixture $>$ triticale/ grazing vetch biennial rotation $>$ triticale/ grazing vetch annual rotation $>$ vetch monoculture.

In 1993, when the cover crops were sown late (24 May), the DMP of triticale $(A B)$, vetch $(A B)$ and dwarf Fescue increased considerably from the end of August to the end of November (Table 4). This trend was evident during 1994 as well, albeit not as prominently. In the case of triticale, the additional amount of dry matter produced from the end of August 1994 to the end of November 1994 was negligible. This trend also did not manifest itself for triticale during the rest of the study, showing that there is no advantage in applying this management practice to triticale if the species was established in mid-April. The winter-growing period being shorter by approximately 40 days in 1993 than in the following seasons meant that the species completed its life cycle at a later stage, which resulted in additional dry matter being produced from the end of August 1993 until the end of November 1993. This supports the results of Fourie et al. (2006b). Vetch produced additional dry matter from the end of August to the end of November during 1997, 1998, 2001 and 2002 (Table 4). With the exception of the 2000 season, vetch produced additional dry matter (Table 4) if the DMP of the species was less than $2.5 \mathrm{t} / \mathrm{ha}$ by the end of August (Table 3). The average additional amount of dry matter produced by vetch over the 10-year period (Table 4) is an indication that the species has a longer life cycle than triticale and that this management practice should be considered for vetch under the circumstances described above. The additional dry matter produced by dwarf Fescue during the 1993 and 1994 seasons can be ascribed to the fact that this perennial grass had not been fully established up to that stage. The additional dry matter produced during 1998 may be attributed to the fact that the species was re-planted during the winter and was in the process of establishing itself.

\section{Control of winter-growing weeds}

In the first year following the establishment of the vineyard in September 1992, the DMP of the winter-growing weeds in T1 (control) and T2 amounted to $1.34 \mathrm{t} / \mathrm{ha}$ and $0.80 \mathrm{t} / \mathrm{ha}$, respectively (Table 5). These relatively poor weed stands suggested that the deep pre-planting soil preparation during 1992 could have had a negative impact on the weed seed population in the topsoil. The DMP of the winter-growing weeds measured in T1 and T2 during 1994 was an indication that the weeds in this region have the ability to re-establish successfully within two years after initial deep soil preparation $(800 \mathrm{~mm})$. A similar trend occurred on a medium-textured soil in the Coastal wine grape region (Fourie et al., 2006b). The significantly higher amount of weed dry matter in $\mathrm{T} 1$ compared to that of $\mathrm{T} 2$ indicated that the disturbance of the soil by means of mechanical cultivation might have brought seeds from the deeper soil layers back to the surface, thereby promoting seed germination and causing the weeds to proliferate in the control. The sharp decline in DMP by the winter-growing weeds in T1 during 1995 indicated that mechanical control applied at the correct time from bud break to harvest could reduce the stand of winter-growing weeds in this region by $46 \%$ within one season.

Continuous, effective suppression of the winter-growing weeds (less than $20 \%$ of the weed stand in the control) was achieved with

\section{TABLE 4}

Change in dry matter production (DMP) of different cover crop species, from just before grapevine bud break (end of August) to when the berries reached pea size (end of November) on a medium-textured soil near Robertson.

\begin{tabular}{|c|c|c|c|c|c|c|c|c|c|c|c|}
\hline \multirow{2}{*}{ Treatment } & \multicolumn{11}{|c|}{ Change in DMP (t/ha) } \\
\hline & $1993^{1}$ & 1994 & 1995 & 1996 & 1997 & 1998 & 1999 & 2000 & 2001 & 2002 & Average \\
\hline Triticale v. Usgen 18 (triticale), $\mathrm{BB}^{2}$ & -0.40 & -0.32 & -0.31 & -1.97 & -3.27 & -0.85 & -4.51 & -3.92 & -3.82 & -0.76 & -2.01 \\
\hline Triticale, $\mathrm{AB}^{3}$ & 2.81 & 0.10 & -1.26 & -2.55 & -3.51 & -3.35 & -2.21 & -3.55 & -1.36 & -5.01 & -1.99 \\
\hline Vicia dasycarpa Ten. (vetch), BB & -0.28 & -0.39 & -0.61 & -2.28 & 0.17 & 0.57 & -2.52 & -0.47 & -1.25 & -0.05 & -0.71 \\
\hline Vetch, AB & 3.69 & 2.58 & -0.76 & -1.64 & 0.87 & 1.29 & -0.72 & -0.36 & 0.64 & 1.10 & 0.67 \\
\hline $\begin{array}{l}\text { Secale cereale L. v. Henog (rye)/Vicia faba } \\
\text { L. v. Fiord (faba bean) mixture, BB }\end{array}$ & -0.22 & -0.13 & -0.56 & -2.43 & -1.10 & -3.31 & -1.62 & -2.10 & -2.15 & -1.66 & -1.53 \\
\hline $\begin{array}{l}\text { Festuca arundinacae L. v. Cochise } \\
\text { (dwarf Fescue), } \mathrm{SL}^{4}\end{array}$ & 1.56 & 0.42 & -0.20 & -2.63 & -0.42 & 1.30 & -0.99 & -0.63 & -0.06 & -0.81 & -0.23 \\
\hline $\operatorname{LSD}(p \leq 0.05)$ & 2.24 & $\mathrm{NS}^{5}$ & NS & NS & 2.78 & 2.27 & 3.26 & 2.67 & 2.77 & 2.96 & 2.72 \\
\hline
\end{tabular}

${ }^{1}$ Cover crops established on 24 May instead of mid-April. ${ }^{2} \mathrm{BB}=$ full surface post-emergence chemical control from the end of August. ${ }^{3} \mathrm{AB}=$ post-emergence chemical control in vine row at the end of August, full surface post-emergence chemical control from the end of November. ${ }^{4} \mathrm{Chemical}$ control in vine row from the end of August, work row slashed throughout the season. ${ }^{5} \mathrm{NS}=$ Data did not differ significantly at the $10 \%$ level. 


\section{TABLE 5}

Effect of different soil cultivation practices on dry matter production (DMP) of winter growing weeds, measured just before grapevine bud break (end of August) on a medium-textured soil near Robertson.

\begin{tabular}{|c|c|c|c|c|c|c|c|c|c|c|c|c|c|}
\hline \multirow{2}{*}{ Treatment } & \multicolumn{13}{|c|}{ DMP (t/ha) } \\
\hline & $1993^{1}$ & 1994 & 1995 & 1996 & 1997 & 1998 & 1999 & 2000 & 2001 & 2002 & 2003 & 2004 & Average \\
\hline No cover crop, $\mathrm{MC}^{2}$ (Control) & 1.34 & 5.10 & 2.77 & 2.69 & 2.48 & 1.57 & 1.93 & 1.94 & 2.45 & 1.45 & 1.83 & 0.92 & 2.21 \\
\hline No cover crop, $\mathrm{BB}^{3}$ & 0.80 & 2.40 & 2.34 & 3.15 & 1.49 & 1.53 & 2.09 & 1.38 & 2.38 & 1.69 & 1.67 & 0.97 & 1.82 \\
\hline Full surface straw mulch, BB & 1.27 & 0.70 & 0.51 & 1.73 & 0.63 & 0.06 & 0.28 & 0.38 & 0.33 & 0.93 & 0.75 & 0.38 & 0.66 \\
\hline Triticale v. Usgen 18 (triticale), BB & 0.43 & 1.00 & 0 & 0 & 0.48 & 0.02 & 0.09 & 0.19 & 0 & 0 & 0 & 0 & 0.19 \\
\hline Triticale, $\mathrm{AB}^{4}$ & 0.25 & 1.10 & 1.61 & 0.93 & 0.10 & 0.30 & 0.46 & 0.54 & 0.40 & 0.62 & 0.70 & 0 & 0.58 \\
\hline Vicia dasycarpa Ten. (vetch), BB & 0.47 & 1.30 & 0.53 & 1.74 & 0.50 & 0.32 & 1.36 & 1.50 & 0.66 & 1.42 & 0.58 & 0.15 & 0.88 \\
\hline Vetch, AB & 0.58 & 1.30 & 0.43 & 1.48 & 0.59 & 1.39 & 2.03 & 1.30 & 1.05 & 2.03 & 1.83 & 0.08 & 1.17 \\
\hline $\begin{array}{l}\text { Secale cereale (rye)/Vicia faba L. } \\
\text { v. Fiord (faba bean) mixture, BB }\end{array}$ & 0.13 & 0.80 & 1.16 & 0.29 & 0.47 & 0.01 & 0.68 & 0.86 & 0.57 & 0.84 & 0.63 & 0 & 0.54 \\
\hline Triticale/vetch rotated annually, BB & $0.14^{\mathrm{t}}$ & 1.80 & $0.05^{\mathrm{t}}$ & 1.15 & $0^{\mathrm{t}}$ & 0.32 & $0.35^{t}$ & 0.95 & $0.14^{\mathrm{t}}$ & 0.53 & $0.35^{\mathrm{t}}$ & 0 & 0.48 \\
\hline Triticale/vetch rotated biennially, BB & $0.16^{\mathrm{t}}$ & $1.60^{t}$ & 0.06 & 0.12 & $0.15^{\mathrm{t}}$ & $0.14^{t}$ & 1.46 & 0.98 & $0^{t}$ & $0^{\mathrm{t}}$ & 0.32 & 0 & 0.42 \\
\hline $\begin{array}{l}\text { Festuca arundinacae L. } \\
\text { v. Cochise (dwarf Fescue), SL }\end{array}$ & 0.31 & 0.80 & 1.00 & 0.35 & 0.73 & 0.22 & 0.41 & 0.82 & 0.79 & 0.66 & 0.97 & 0.02 & 0.59 \\
\hline $\operatorname{LSD}(p \leq 0.05)$ & 0.59 & 1.15 & 1.14 & 1.66 & 1.08 & 0.94 & 1.53 & 1.06 & 0.74 & 1.17 & 1.11 & 0.55 & 1.06 \\
\hline
\end{tabular}

${ }^{1}$ Cover crops established on 24 May instead of mid-April. ${ }^{2} \mathrm{MC}=$ post-emergence chemical control in vine row and mechanical control in working row from the end of August. ${ }^{3} \mathrm{BB}=$ full surface post-emergence chemical control from the end of August. ${ }^{4} \mathrm{AB}=$ post-emergence chemical control in vine row at the end of August, full surface post-emergence chemical control from when the grape berries reached pea size (end of November). ${ }^{5} \mathrm{Chemical}$ control in vine row from the end of August, work row slashed throughout the season. ${ }^{\mathrm{t}}$ Year in which triticale was sown.

triticale in T4 from 1994 onwards (Table 5). Total suppression of the winter-growing weeds was achieved in T4 from 1995 to 1996 and again from 2001 to 2004 . This enabled a $50 \%$ reduction in glyphosate applied for post-emergence weed control at the end of August during those years. Despite the fact that total suppression of the winter-growing weeds was not achieved during 1998 and 1999, the reduced amount of glyphosate could still be applied. Effective winter weed suppression was achieved in the years in which triticale was established in $\mathrm{T} 9$ and $\mathrm{T} 10$. Total suppression of the winter-growing weeds was achieved in T10 during 2001 to 2002 , also allowing a $50 \%$ reduction in the amount of glyphosate applied at the end of August. Although similar amounts of dry matter were produced by triticale in T4 and T5 (Table 3), triticale suppressed the winter-growing weeds in T5 effectively during the 1993, 1997, 1998 and 2004 seasons only (Table 5). The relatively poorer weed suppression in T5 compared to that of T4 was attributed inter alia to the winter weeds being allowed to complete their life cycle in the first-mentioned treatment and produce seeds that could germinate in the following winter, thus adding to the seed population in the top soil layer. The weed suppression capabilities of triticale in combination with BB resulted in effective weed suppression being achieved in $\mathrm{T} 4$ and T10 over the long term.

Effective suppression of the winter-growing weeds was achieved with the full surface straw mulch and BB combination in T3 from 1994 to 1995 and from 1998 to 2001 (Table 5). The weed suppression by this treatment was, however, insignificant in 1993, 1996 and from 2002 to 2004 . This erratic weed control pattern was attributed to the straw being contaminated with varying amounts of weed seeds, thereby replenishing the seed population in the topsoil. Although effective winter weed suppression was not achieved with this management practice over the long term, the average winter weed stand was significantly reduced compared to that of the control.

Vetch suppressed the winter-growing weeds in T6 and T7 effectively during the 1995 and 2004 seasons (Table 5). The average weed stand in these two treatments was, however, not significantly lower than that of T1 (control), indicating that these treatments did not suppress the winter-growing weeds effectively in the long-term. When rotated biennially with triticale, vetch suppressed the winter-growing weeds effectively from 1995 to 1996 and from 2003 to 2004 . This was attributed to the effective (1993 and 1994) and total (2001 and 2002) control achieved with triticale in $\mathrm{T} 10$ in the preceding two-year periods, which may have reduced the seed population in the topsoil, thus enabling vetch to maintain the status quo.

The rye/faba bean mixture (T8) suppressed the winter-growing weeds effectively from 1993 to 1994, from 1996 to 1998 and in 2004. The weed suppression by this treatment was, however, insignificant during 1993 and 1996, as well as from 2002 to 2004. Although effective winter weed suppression was not achieved with this management practice over the long term, the average 
TABLE 6

Effect of different soil cultivation practices on dry matter production (DMP) of weeds growing from just before grapevine bud break (end of August) to when the berries reached pea size (end of November).

\begin{tabular}{|c|c|c|c|c|c|c|c|c|c|c|c|c|c|}
\hline \multirow{2}{*}{ Treatment } & \multicolumn{13}{|c|}{$\operatorname{DMP}(\mathrm{t} / \mathrm{ha})$} \\
\hline & $1993^{1}$ & 1994 & 1995 & 1996 & 1997 & 1998 & 1999 & 2000 & 2001 & 2002 & 2003 & 2004 & Average \\
\hline No cover crop, $\mathrm{MC}^{2}$ (Control) & 1.02 & 2.00 & 2.03 & 2.53 & 1.57 & 0.97 & 1.97 & 1.78 & 0.66 & 1.98 & 0.92 & 0.76 & 1.52 \\
\hline No cover crop, $\mathrm{BB}^{3}$ & 1.43 & 3.20 & 2.42 & 1.09 & 0.66 & 0.61 & 0.91 & 0.76 & 0.96 & 1.42 & 0.97 & 0.48 & 1.24 \\
\hline Full surface straw mulch, BB & 1.53 & 2.20 & 2.46 & 1.71 & 1.06 & 0.08 & 0.45 & 0.11 & 0 & 0 & 0 & 0.17 & 0.81 \\
\hline Triticale v. Usgen 18 (triticale), BB & 0.60 & 2.90 & 0.69 & 0.21 & 0.07 & 0.03 & 0.31 & 0.07 & 0 & 0 & 0 & 0.03 & 0.41 \\
\hline Triticale, $\mathrm{AB}^{4}$ & 1.64 & 1.60 & 0.67 & 0.37 & 0.12 & 0.57 & 0.26 & 0.22 & 0 & 0.18 & 0 & 0.16 & 0.48 \\
\hline Vicia dasycarpa Ten. (vetch), BB & 0.98 & 3.30 & 0.66 & 0.98 & 0.42 & 0.39 & 0.61 & 0.41 & 0.38 & 0.29 & 0.15 & 0.48 & 0.75 \\
\hline Vetch, AB & 2.15 & 2.40 & 1.03 & 1.73 & 1.27 & 1.05 & 0.12 & 0.93 & 0.18 & 0.91 & 0.17 & 0.13 & 1.01 \\
\hline $\begin{array}{l}\text { Secale cereale (rye)/Vicia faba L. v. } \\
\text { Fiord (faba bean) mixture, BB }\end{array}$ & 1.07 & 2.60 & 0.77 & 0.23 & 0.32 & 0.10 & 0.05 & 0.32 & 0 & 0 & 0 & 0.04 & 0.46 \\
\hline Triticale/vetch rotated annually, BB & $1.51^{\mathrm{t}}$ & 1.50 & $1.09^{\mathrm{t}}$ & 0.62 & $0.21^{\mathrm{t}}$ & 0.46 & $0.18^{\mathrm{t}}$ & 0.30 & $0^{\mathrm{t}}$ & 0.54 & $0^{\mathrm{t}}$ & 0.06 & 0.54 \\
\hline Triticale/vetch rotated biennially, BB & $0.39^{t}$ & $2.70^{t}$ & 0.49 & 1.67 & $0.57^{\mathrm{t}}$ & $0.05^{\mathrm{t}}$ & 0.58 & 0.46 & $0^{\mathrm{t}}$ & $0^{\mathrm{t}}$ & 0 & 0.11 & 0.59 \\
\hline $\begin{array}{l}\text { Festuca arundinacae L. v. Cochise } \\
\text { (dwarf Fescue), } \text { SL }^{5}\end{array}$ & 2.82 & 2.40 & 2.03 & 1.82 & 2.22 & 1.14 & 1.60 & 1.27 & 0.24 & 1.54 & 1.02 & 0.59 & 1.56 \\
\hline $\operatorname{LSD}(p \leq 0.05)$ & 1.25 & 0.74 & 0.77 & 1.04 & 1.01 & 0.75 & 0.74 & 0.75 & 0.53 & 0.68 & 0.55 & 0.58 & 0.78 \\
\hline
\end{tabular}

${ }^{1}$ Cover crops established on 24 May instead of mid-April. ${ }^{2} \mathrm{MC}=$ post-emergence chemical control in vine row and mechanical control in working row from the end of August. ${ }^{3} \mathrm{BB}=$ full surface post-emergence chemical control from the end of August. ${ }^{4} \mathrm{AB}=$ post-emergence chemical control in vine row at the end of August, full surface post-emergence chemical control from the end of November. ${ }^{5} \mathrm{Chemical}$ control in vine row from the end of August, work row slashed throughout the season. 'Year in which triticale was sown.

winter weed stand was significantly reduced compared to that of the control. The results achieved with dwarf Fescue (T11) was similar to that achieved with triticale controlled chemically when the grapevine berries reached pea size (T5), as managing the soil in this manner also allowed the winter-growing weeds to complete their life cycle and produce seeds. The decline in the winter weed stand from 1997 to 1998 in T11 was attributed to the re-establishment of the dwarf Fescue. The mechanical cultivation during seedbed preparation in March must have controlled the perennial species prevalent in $\mathrm{T} 11$, thus reducing the weed pressure in the short term.

\section{Control of summer-growing weeds}

\section{From grapevine bud break (early September) to when the berries reached pea size (end of November)}

The weed-control efficacy of the cover crop treatments (T4 to T11), measured at the end of November in 1993 and 1994, did not surpass that of T1, the control treatment (Table 6). The weed stand in T11 was significantly higher than that of T1 during the 1993 season. The same trend was also detected in T2, T4 and T6 during the 1994 season. The reason for this is not clear. From the 1995 season onwards, the weed stand in T4 and T8 was significantly less than that of T1. This trend was detected in T9 and T5 as well, with the exception of the 1998 season. From the 1998 season onwards, the weed stand in T3 and T10 was significantly lower than that of T1. Long-term average weed DMP indicated that BB applied to a cover crop system that includes a grain species reduced the summer weed stand at the end of November significantly compared to T1 or T11.

Total weed control was achieved from 2001 to 2003 in T3, T4, T8 and T10. This was also achieved in T5 and T9 during 2001 and 2003. The herbicide application at the end of November could therefore be omitted from these treatments in 2001 and 2003 and, in the case of T3, T4, T8 and T10, also in 2002. The abovementioned results indicated that meaningful differences in weed control efficacy between soil cultivation practices only manifested three years after application, while total control of summer-growing weeds may only be achieved after a practice has been applied for eight consecutive seasons.

\section{From when the berries reached pea size (end of November) to just before harvest (end of January)}

The stand of weeds in T3, T4, T5 T6 and T8 was significantly lower than that in T1 (control) throughout the five seasons following the implementation of the different soil cultivation treatments (Table 7). Although more dry matter was produced by vetch in T7 than in T6 at the end of November from 1993 to 1997 (Tables 3 and 4), the weed stand in T7 at the end of January in 1994, 1995 and 1998 was significantly higher than that of T6 (Table 7). This was attributed to the weeds in $\mathrm{T} 7$ being allowed to produce seeds, probably increasing the weed pressure in this treatment. The stand of weeds in T9 and T10 was always significantly lower than that of $\mathrm{T} 1$ (control) during the years in which triticale was 
TABLE 7

Effect of different soil cultivation practices on dry matter production (DMP) of the weeds growing from when the berries reached pea size (end of November) to just before harvest (end of January).

\begin{tabular}{|c|c|c|c|c|c|c|}
\hline \multirow{2}{*}{ Treatment } & \multicolumn{6}{|c|}{ DMP (t/ha) } \\
\hline & $1994^{1}$ & 1995 & 1996 & 1997 & 1998 & Average \\
\hline No cover crop, $\mathrm{MC}^{2}$ (Control) & 3.63 & 1.30 & 1.70 & 1.73 & 1.29 & 1.93 \\
\hline No cover crop, $\mathrm{BB}^{3}$ & 0.86 & 0.80 & 1.74 & 1.72 & 0.54 & 1.13 \\
\hline Full surface straw mulch, BB & 0.34 & 0.10 & 0 & 0.41 & 0.50 & 0.27 \\
\hline Triticale v. Usgen 18 (triticale), BB & 0.56 & 0.20 & 0 & 0.04 & 0.54 & 0.27 \\
\hline Triticale, $\mathrm{AB}^{4}$ & 1.27 & 0.20 & 0 & 0.01 & 0.17 & 0.53 \\
\hline Vicia dasycarpa Ten. (vetch), BB & 0.56 & 0.40 & 0 & 0.42 & 0.33 & 0.34 \\
\hline Vetch, AB & 1.87 & 1.11 & 0 & 1.13 & 1.22 & 1.06 \\
\hline Secale cereale (rye)/Vicia faba L. v. Fiord (faba bean) mixture, BB & 0.40 & 0.20 & 0 & 0.16 & 0.18 & 0.19 \\
\hline Triticale/vetch rotated annually, BB & $0.93^{\mathrm{t}}$ & 0.90 & $0.02^{\mathrm{t}}$ & 0.19 & $0.51^{\mathrm{t}}$ & 0.51 \\
\hline Triticale/vetch rotated biennially, BB & $1.33^{\mathrm{t}}$ & $0.20^{\mathrm{t}}$ & 0.46 & 0.88 & $0.44^{\mathrm{t}}$ & 0.68 \\
\hline Festuca arundinacae L. v. Cochise (dwarf Fescue), $\mathrm{SL}^{5}$ & 1.50 & 1.60 & 1.45 & 1.60 & 2.54 & 1.74 \\
\hline $\operatorname{LSD}(p \leq 0.05)$ & 0.94 & 0.70 & 0.62 & 0.92 & 0.69 & 0.77 \\
\hline
\end{tabular}

${ }^{1}$ Cover crops established on 24 May instead of mid-April. ${ }^{2} \mathrm{MC}=$ post-emergence chemical control in vine row and mechanical control in working row from just before grapevine bud break (end of August). ${ }^{3} \mathrm{BB}=$ full surface post-emergence chemical control from the end of August. ${ }^{4} \mathrm{AB}=$ post-emergence chemical control in vine row at the end of August, full surface post-emergence chemical control from the end of November. ${ }^{5}$ Chemical control in vine row from the end of August, work row slashed throughout the season. 'Year in which triticale was sown.

used as cover crop. Significant weed suppression by vetch in these treatments seemed to depend on effective weed suppression during the previous year.

\section{CONCLUSIONS}

Triticale has the ability to produce significantly more dry matter than the local weeds over the long term if sown in mid-April, irrespective of the management practice applied. Rotating triticale and vetch annually or biennially did not improve the dry matter production of these species over the long term. This indicated that, under similar environmental conditions, mono-cropping can be applied with these two species for as long as 11 years without a significant loss in the production of dry matter. The data suggest that a grain species such as triticale and rye should be an integral part of any cover cropping system in the Breede River Valley. If the cover crop can only be established late in May, it seems prudent to allow the cover crop to keep on growing after grapevine bud break in order to facilitate additional growth from grapevine bud break to grapevine berry set, thus maximising dry matter production. When sown in mid-April, this management practice should be considered for vetch only.

Meaningful differences in weed control efficacy between treatments became evident only three years after application, illustrating the importance of and need for long-term soil cultivation trials in crops. Effective winter weed suppression, as well as significantly improved summer weed control, may be achieved in this grapevine region with triticale controlled chemically full surface from bud break. This cultivation practice results in total suppression of winter-growing weeds over the medium to long term, which allows a reduction in the application of herbicides. Triticale, a rye/faba bean mixture or a biennial rotation of triticale and vetch as cover crop, in combination with full surface chemical control during bud break, as well as combining full surface straw mulch with full surface chemical control during bud break, may achieve total summer weed control after eight years of application. This allows producers to omit the herbicide spray that is usually given in irrigated vineyards in this semi-arid region when the grapevine berries reach pea size. A permanent cover crop or mechanical cultivation in the work row did not suppress the winter- and summer-growing weeds significantly.

\section{LITERATURE CITED}

Booysen, J.H., Steenkamp, J. \& Archer, E., 1992. Names of vertical trellising systems (with abbreviations). Wynboer September, 15.

Buckerfield, J.C. \& Webster, K.A., 1996. Earthworms, mulching, soil moisture and grape yields. Wine Indust. J. 11, 47-53.

Carter, A.D., Hollis, J.M., Thompson, T.R.E., Oakes, D.B. \& Binneyu, R., 1991. Pesticide contamination of water sources: current policies for protection and a multi-disciplinary proposal to aid future planning. Brighton Crop Prot. Conf. Weeds 2, 491-498.

Cousens, R. \& Mortimer, M., 1995 ( $1^{\text {st }}$ ed). Dynamics of weed populations. Cambridge University Press, Cambridge.

Darmency, H. \& Gasquez, J.,1990. The fate of herbicide resistant genes in weeds. In: Green, M.B., LeBaron, H.M. \& Moberg, W.K. (eds). Managing resistance to agrochemicals: from fundamental research to practical strategies. American Chemical Society, Washington DC.

Fourie, J.C., 2005. Cover crop management in the vineyards of the Lower Orange River region, South Africa: 1. Performance of grass and broadleaf species. S. Afr. J. Enol. Vitic. 26, 140-146. 
Fourie, J.C., Louw, P.J.E. \& Agenbag, G.A., 2001. Effect of seeding date on the performance of grasses and broadleaf species evaluated for cover crop management in two wine grape regions of South Africa. S. Afr. J. Plant Soil 18, 118-127.

Fourie, J.C., Louw, P.J.E. \& Agenbag, G.A., 2005. Cover crop management in a Sauvignon blanc/Ramsey vineyard in the semi-arid Olifants River Valley, South Africa. 1. Effect of management practices on selected grass and broadleaf species. S. Afr. J. Enol. Vitic. 26, 131-139.

Fourie, J.C., Louw, P.J.E. \& Calitz, F.J., 2006a. Effect of seeding date on the performance of grasses and broadleaf species evaluated for cover crop management in the Breede River Valley wine grape region of South Africa. S. Afr. J. Enol. Vitic. $27,8-14$.

Fourie, J.C., Louw, P.J.E. \& Agenbag, G.A., 2006b. Cover crop management in a Chardonnay/99 Richter vineyard in the Coastal wine grape region, South Africa. 1. Effect of two management practices on selected grasses and broadleaf species. S. Afr. J. Enol. Vitic. 27, 167-177.

Henkes, R., 1997. Handling herbicide resistance. The Furrow 102, 8-11.

Khan, M.J., Monke, E.J. \& Foster, G.R., 1986. Mulch cover and canopy effect on soil loss. Pap. ASAE no 86-253. Dept of Agric. Eng. Purdue Univ. West Lafayette, In. 47907, USA.

Lamprecht, S.C., Knox-Davies, P.S., Marasas, W.F.O. \& Calitz, F.J., 1988. Fungi associated with root rot of annual Medicago spp. in South Africa. Phytophyl. 20, 281-286.

Lamprecht, S.C., Marasas, W.F.O., Knox-Davies, P.S. \& Calitz, F.J., 1990. Incidence of Fusarium species in different cropping systems of annual Medicago species and wheat. Phytophyl. 22, 69-76.

LeBaron, H.M., 1991. Distribution and seriousness of herbicide-resistant weed infestations worldwide. In: Caseley, J.C., Cussans, G.W. \& Atkin, R.K. (eds). Herbicide resistance in weeds and crops. Butterworth-Heinemann, Boston. pp. $27-43$.
LeBaron, H.M. \& McFarland, J.E., 1990. Herbicide resistance in weeds and crops: an overview and prognosis. In: Green, M.B., LeBaron, H.M. \& Moberg, W.K. (eds). Managing resistance to agrochemicals: from fundamental research to practical strategies. American Chemical Society, Washington DC.

Louw, P.J.E. \& Bennie, A.T.P., 1992. Water runoff and soil erosion in vineyard soils. Austr. Grapegrower \& Winemaker Annual Technical Issue, 100-113.

Major, C.S., 1992. Addressing public fears over pesticides. Weed Technol. 6, 471472 .

Powles, S.B., Preston, C., Bryan, I.B. \& Jutsum, A.R., 1997. Herbicide resistance impact and management. Adv. Agron. 58, 57-93.

Roth, C.H., Meyer, B., Frede, G. \& Derpsch, R., 1988. Effect of mulch rates and tillage systems on infiltrabillity and other soil physical properties of an Oxisol in Parana, Brazil. Soil \& Tillage Res. 11, 81-91.

SAS, $1990\left(1^{\text {st }}\right.$ ed). SAS/STAT user's guide, version 8, volume 2. SAS Institute Inc., Cary NC.

Shapiro, S.S. \& Wilk, M.B., 1965. An analyses of variance test for normality (complete samples). Biometrika 52, 591-611.

Soil Classification Work Group, 1991. Soil classification - A taxonomic system for South Africa. Department of Agricultural Development: Memoirs on natural agricultural resources of South Africa No. 15, Department of Agricultural Development, Pretoria, South Africa.

The Non-Affiliated Soil Analysis Work Committee, 1990. Handbook of standard soil testing methods for advisory purposes. Soil Sci. Soc. South Africa, Sunnyside, Pretoria.

Van Huyssteen, L., Van Zyl, J.L. \& Koen, A.P., 1984. The effect of cover crop management on soil conditions and weed control in a Colombar vineyard in Oudtshoorn. S. Afr. J. Enol. Vitic. 5, 7-17. 